Volume 15 Issue 1

DOI: http://dx.doi.org/10.53772/NMO.2021.15105

\title{
Role of microbiology laboratory in diagnosis of sars cov-2 (Covid -19)
}

\author{
Madhulika Mistry \\ Corresponding Author: \\ Dr. Madhulika Mistry, \\ Associate Professor- Department of Microbiology, \\ Laboratory Director- NABL, \\ PDU government Medical College, \\ Rajkot- Gujarat. \\ Email: madhulika_mistry@yahoo.co.in
}

\section{Introduction:}

\section{From the Common Cold to Global Contagion}

Coronaviruses causes respiratory tract infections in man; illness ranging from mild common cold to severe diseases like pneumonia and most of them belonging to Beta corona virus except the first two (229E and NL63) which belong to Alpha corona virus.
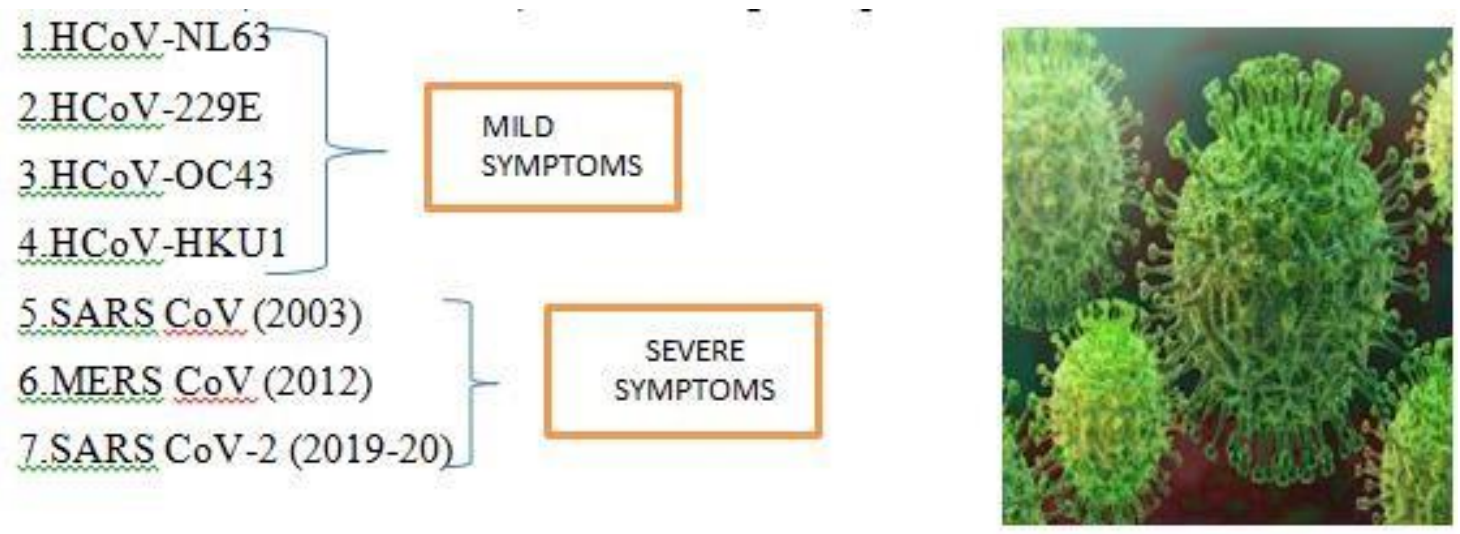

SARS-CoV-2 is a respiratory transmitting virus that causes flu-like condition and, in some cases, severe acute respiratory syndrome (SARS). However, COVID-19 patients have shown that the virus is capable of causing symptoms outside the respiratory tract, in addition to complications of an inflammatory nature in several organs, expanding the spectrum of associated clinical manifestations.

With any viral infection, the gold standard for diagnosis is identification of the infectious agent by visualizing viral particles at electron microscopy, identifying intracellular viral inclusions at 
light microscopy or tissue cultures for in vitro virus replication. These methods available only in research centers.

In commercial laboratories, immune enzymatic assays or agglutination tests are available for detection of viral antigens and nucleic acid amplification tests for detection of virus genetic material.

\section{The timeline of the facts of COVID-19}

\begin{tabular}{|c|c|}
\hline DATE & FACTS \\
\hline Dec 8, 2019 & $\begin{array}{l}\text { Reported first known case of pneumonia of unknown etiology in } \\
\text { Wuhan. }\end{array}$ \\
\hline Dec 31, 2019 & $\begin{array}{l}\text { China reports a cluster of cases of pneumonia with unknown etiology in } \\
\text { Wuhan to WHO. }\end{array}$ \\
\hline Jan 7, 2020 & A novel coronavirus 2019 was identified. \\
\hline Jan 10,2020 & Viral genome sequence was released. \\
\hline Jan 12,2020 & Four other genome sequences deposited in the viral sequence database. \\
\hline Jan 31,2020 & $\begin{array}{l}\text { WHO declares a public health emergency of international concern } \\
\text { (PHEIC). }\end{array}$ \\
\hline Feb 11, 2020 & WHO named the disease as COVID-19. \\
\hline Feb 11, 2020 & Virus is renamed as SARS-CoV-2. \\
\hline Mar 11, 2020 & WHO declared COVID- 19 as global pandemic. \\
\hline
\end{tabular}

\section{Specimen}

Proper specimen collection is the most important step in the laboratory diagnosis of infectious diseases. A specimen that is not collected correctly may lead to false or inconclusive test results.

Specimens to be collected at minimum is respiratory material: - upper respiratory specimens: nasopharyngeal and oropharyngeal swab or wash in ambulatory patients - and/or lower respiratory specimens: sputum (if produced) and/or endotracheal aspirate or bronchoalveolar lavage in patients with more severe respiratory disease.

Additional clinical specimens may be collected as COVID-19 virus has been detected in blood and stool, as had the coronaviruses responsible for SARS and MERS. The duration and frequency of shedding of COVID-19 virus in stool and potentially in urine is unknown. In case of patients who are deceased, consider autopsy material including lung tissue. In surviving 
patients, paired serum (acute and convalescent) can be useful to retrospectively define cases as serological assays become available.

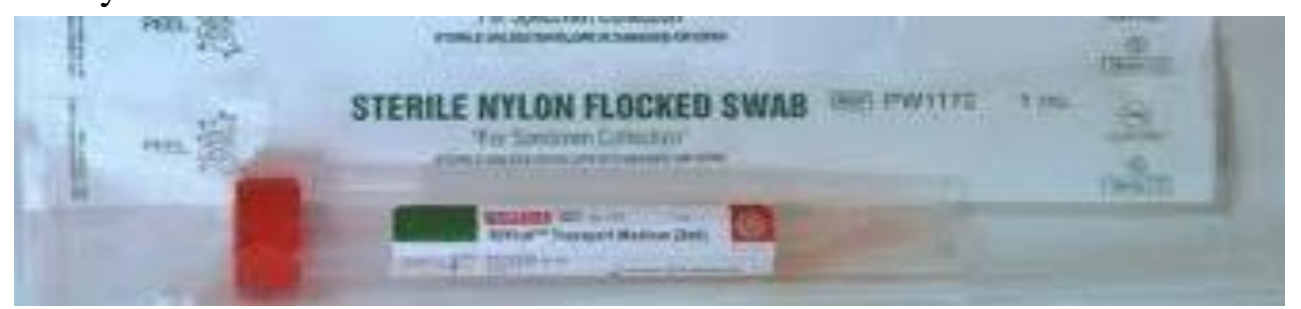

Specimen in Table 1

\begin{tabular}{|l|l|}
\hline UPPER & $\bullet$ Nasopharyngeal swab \\
RESPIRATORY & $\bullet$ Oropharyngeal swab \\
\hline LOWER & $\bullet$ Endotracheal aspirate \\
RESPIRATORY & $\bullet$ Bronchoalveolar lavage \\
\hline OTHER & $\bullet$ Stool \\
SPECIMEN & $\bullet$ Blood \\
& - Paired serum \\
& - Autopsy material including \\
& \\
& lung tissue \\
\hline
\end{tabular}

Specimen collection details proposed by the WHO have been presented in Table 2

\begin{tabular}{|c|c|c|c|c|}
\hline Specimen type & $\begin{array}{l}\text { Collection } \\
\text { materials }\end{array}$ & $\begin{array}{l}\text { Transport } \\
\text { to } \\
\text { laboratory }\end{array}$ & $\begin{array}{l}\text { Storage } \\
\text { temperature till } \\
\text { testing }\end{array}$ & Comments \\
\hline $\begin{array}{l}\text { Nasopharyngeal and } \\
\text { oropharyngeal } \\
\text { swaba }\end{array}$ & $\begin{array}{l}\text { Dacron or } \\
\text { polyester flocked } \\
\text { swabs }^{b}\end{array}$ & $4^{\circ} \mathrm{C}$ & $\begin{array}{l}\leq \text { Sdays }: 4^{\circ} \mathrm{C} \\
>5 \text { days : }-70^{\circ} \mathrm{C}\end{array}$ & $\begin{array}{l}\text { To increase the viral load both } \\
\text { nasopharyngeal and oropharyngeal } \\
\text { swabs should be placed in the same } \\
\text { tube }\end{array}$ \\
\hline $\begin{array}{l}\text { Bronchoalveolar } \\
\text { lavage }\end{array}$ & Sterile container ${ }^{b}$ & $4^{\circ} \mathrm{C}$ & $\begin{array}{l}\leq 48 \text { hours : } 4^{\circ} \mathrm{C} \\
>48 \text { hours: }-70^{\circ} \mathrm{C}\end{array}$ & $\begin{array}{l}\text { Some dilution of pathogen may be } \\
\text { there but a important specimen in } \\
\text { patients with serious infection }\end{array}$ \\
\hline $\begin{array}{l}\text { Tracheal aspirate, } \\
\text { nasopharyngeal } \\
\text { aspirate or nasal } \\
\text { wash }\end{array}$ & Sterile container ${ }^{b}$ & $4^{\circ} \mathrm{C}$ & $\begin{array}{l}\leq 48 \text { hours : } 4^{\circ} \mathrm{C} \\
>48 \text { hours: }-70^{\circ} \mathrm{C}\end{array}$ & - \\
\hline Sputum & Sterile container & $4^{\circ} \mathrm{C}$ & $\begin{array}{l}\leq 48 \text { hours : } 4^{\circ} \mathrm{C} \\
>48 \text { hours : }-70^{\circ} \mathrm{C}\end{array}$ & $\begin{array}{l}\text { To ensure if the material is from } \\
\text { lower respiratory tract }\end{array}$ \\
\hline $\begin{array}{l}\text { Tissue from biopsy } \\
\text { or autopsy including } \\
\text { from lung }\end{array}$ & $\begin{array}{l}\text { Sterile container } \\
\text { with saline or } \\
\text { VTM }\end{array}$ & $4^{\circ} \mathrm{C}$ & $\begin{array}{l}\leq 24 \text { hours: } 4^{\circ} \mathrm{C} \\
>24 \text { hours: }-70^{\circ} \mathrm{C}\end{array}$ & $\begin{array}{l}\text { Important for post mortem } \\
\text { diagnosis }\end{array}$ \\
\hline $\begin{array}{l}\text { Serum (acute and } \\
\text { convalescent } \\
\text { samples) }\end{array}$ & $\begin{array}{l}\text { Serum separator } \\
\text { tubes (adults: } \\
\text { collect } 3-5 \mathrm{ml} \\
\text { whole blood) }\end{array}$ & $4^{\circ} \mathrm{C}$ & $\begin{array}{l}\leq 5 \text { days }: 4^{\circ} \mathrm{C} \\
>5 \text { days : }-70^{\circ} \mathrm{C}\end{array}$ & $\begin{array}{l}\text { Paired samples to be collected: } \\
\text { Acute - first week of illness } \\
\text { Chronic - } 2 \text { to } 3 \text { weeks later }\end{array}$ \\
\hline Whole blood (5ml) & Blood in EDTA vial & $4^{\circ} \mathrm{C}$ & $\begin{array}{l}\leq \text { Sdays : } 4^{\circ} \mathrm{C} \\
>5 \text { days: }-70^{\circ} \mathrm{C}\end{array}$ & - \\
\hline Stool & Stool container & $4^{\circ} \mathrm{C}$ & $\begin{array}{l}\leq 5 \text { days }: 4^{\circ} \mathrm{C} \\
>5 \text { days : }-70^{\circ} \mathrm{C}\end{array}$ & $\begin{array}{l}\text { Important sample to rule out } \\
\text { gastrointestinal infection }\end{array}$ \\
\hline Urine & $\begin{array}{l}\text { Urine collection } \\
\text { container }\end{array}$ & $4^{\circ} \mathrm{C}$ & $\begin{array}{l}\leq 5 \text { days }: 4^{\circ} \mathrm{C} \\
>5 \text { days }:-70^{\circ} \mathrm{C}\end{array}$ & - \\
\hline
\end{tabular}




\section{Laboratory testing for COVID-19 virus:}

1. Nucleic acid amplification tests (NAAT)

2. Antigen and Antibody detection test

3. Viral sequencing

4. Viral culture

\section{NUCLEIC ACID AMPLIFICATION TEST (NAAT): rRT PCR}

The SARS-CoV-2 genome is approximately 30,000 nucleotides in length and encodes several proteins including an RNA-dependent RNA polymerase (RdRP) and four structural proteins viz., nucleocapsid protein $(\mathrm{N})$, spike protein $(\mathrm{S})$, envelope protein $(\mathrm{E})$, and membrane protein $(\mathrm{M})$. RdRP helps in maintaining fidelity of viral genome by acting in conjunction with non-structural proteins, and the spike protein (S) plays an important role in transmission of the virus by functioning in receptor binding and membrane fusion in the host. The S gene of the SARS-CoV2-encoding spike protein is found to have $<75 \%$ nucleotide sequence similarity when compared to other SARS-related coronaviruses. The E, M, and N structural proteins are more conserved than the spike protein and are essential for general function of coronavirus.

Currently, the laboratory diagnosis of SARS-CoV-2 is based on nucleic acid amplification tests (NAAT) like real-time reverse transcriptase (RT-PCR). Various genes are targeted as a part of screening and confirmation of cases. These assays are highly sensitive and specific and do not cross-react with other coronavirus or human clinical samples that contain respiratory viruses.

The presence of an active infection, by targeting specific gene sequences of SARS-CoV-2. It typically has a very low limit of detection; around 100 viruses $/ \mathrm{mL}$. Specimen handling for molecular testing would require BSL-2 or equivalent facilities.

Limitation is it requires time to complete the test and trained personnel and special equipment to analyse the results.

\section{Molecular (rRT-PCR) tests have generally targeted a combination of the following genes:}

1) Envelope (E)

2) RNA dependent RNA polymerase (RdRp)

3) Nucleocapsid (N)

4) Open reading frame $1 \mathrm{ab}(\mathrm{ORF} 1 \mathrm{ab})$

\begin{tabular}{|c|c|c|}
\hline Test & $\begin{array}{l}\text { Molecular } \\
\text { targets }\end{array}$ & Scope \\
\hline \multicolumn{3}{|l|}{ WHO } \\
\hline & E gene & First-line screening \\
\hline & RdRp gene & Confirmatory testing \\
\hline & N gene & $\begin{array}{l}\text { Additional confirmatory } \\
\text { testing }\end{array}$ \\
\hline \multicolumn{3}{|l|}{ CDC } \\
\hline & $\mathrm{N} 1 / 2 / 3$ gene & Combined assay \\
\hline & RNase P gene & Control assay \\
\hline
\end{tabular}



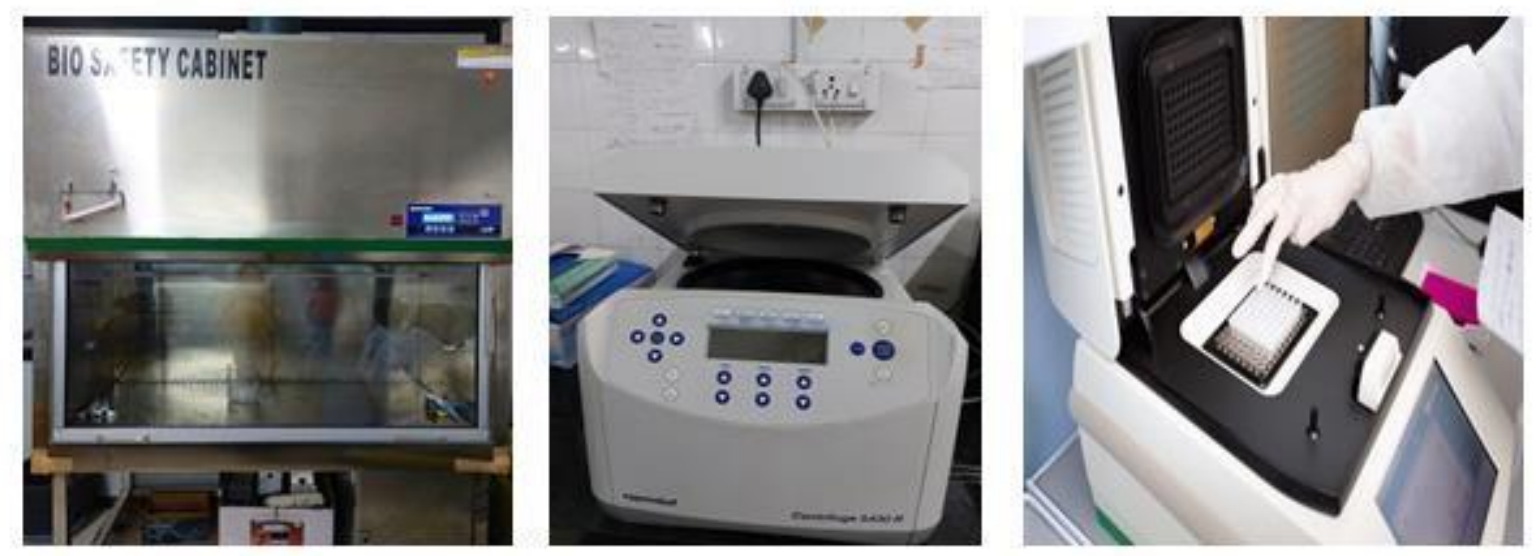

SAMPLE

PROCESSING AND

ALIQUOTING

\section{RNA EXTRACTION}

PRE-PCR AND PCR PLATING

\begin{tabular}{|l|l|}
\hline $\begin{array}{l}\text { Reverse } \\
\text { Transcription }\end{array}$ & $55^{\circ} \mathrm{C}$ for $30 \mathrm{~min}$ \\
\hline $\begin{array}{l}\text { Taq inhibitor } \\
\text { inactivation }\end{array}$ & $95^{\circ} \mathrm{C}$ for $3 \mathrm{~min}$ \\
\hline $\begin{array}{l}\text { PCR Amplification } \\
\text { (45 cycles) }\end{array}$ & $95^{\circ} \mathrm{C}$ for $15 \mathrm{sec}$ \\
\cline { 2 - 2 } & $\begin{array}{l}58^{\circ} \mathrm{C} \text { for } 30 \mathrm{sec} \text { (data } \\
\text { collection) }\end{array}$ \\
\hline
\end{tabular}

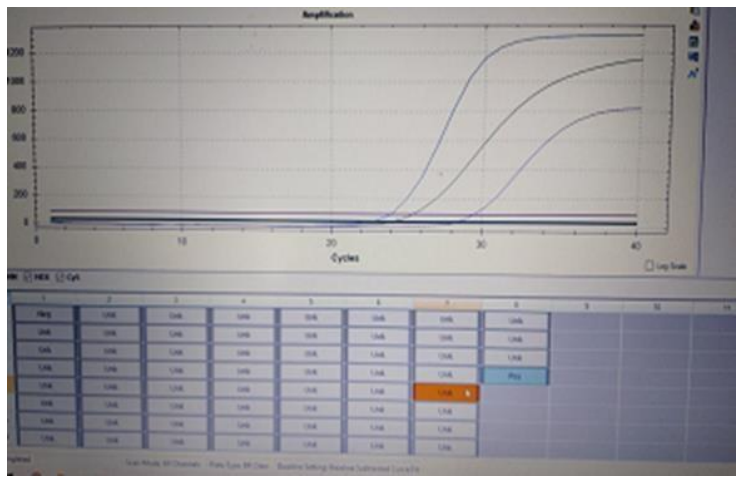

Potential vulnerabilities in the laboratory diagnosis of coronavirus disease 2019 (COVID19) using rRT- PCR:

- $\quad$ Potential vulnerabilities

- Preanalytical

- General

- $\quad$ Specific

- Analytical

\section{Preanalytical:}

\section{A) General factors:}

1. Lack of identification/misidentification.

2. Inadequate procedures for specimen (e.g. swab) collection, handling, transport and storage.

3. Collection of inappropriate or inadequate material for quality or volume.

4. Presence of interfering substances.

5. Manual (pipetting) errors. 
B) Specific factors:

1. Sample contamination.

2. Testing in patients receiving antiretroviral therapy.

\section{Analytical factors:}

1. Testing carried out outside of the diagnostic window.

2. Active viral recombination.

3. Use of non-adequately validated assays.

4. Lack of harmonization of primers and probes.

5. Instrument malfunctioning.

6. Insufficient or inadequate material.

7. Non-specific PCR annealing.

8. Misinterpretation of expression profiles.

\section{Other molecular techniques available are:}

1. Cartridge based nucleic acid amplification testing (CBNAAT): CBNAAT test should be run under biosafety 2 level (BSL-2) conditions and with appropriate biosafety precautions. This test detects $\mathrm{E}$ gene and also the SARS-CoV-2 specific $\mathrm{N} 2$ region of the $\mathrm{N}$ gene.

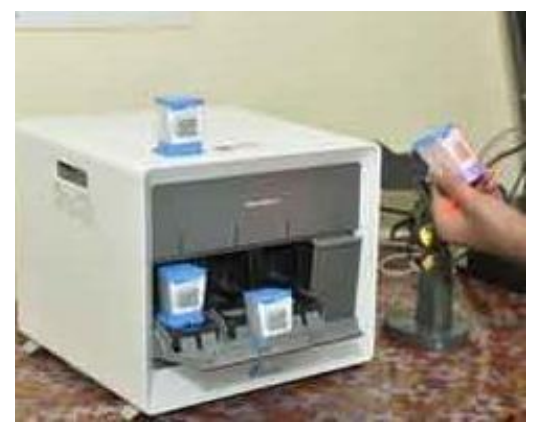

\section{E GENE \& N GENE}

2. TruNAT: TruNat beta CoV test, a microchip-based real-time PCR assay, runs on TruNat machines with a very short test duration of $1 \mathrm{~h}$. It is a chip-based, real-time quantitative PCR system that is portable, battery-operated, fully automated, and weighs around $3 \mathrm{~kg}$. This system can be used in remote areas and has network data transfer ability and an automated reporting system. The advantage of TruNAT is that the virus is lysed during the testing process, minimizing the risk of infection and contamination by the virus. The TruNat test is a semiquantitative real-time PCR assay that has two steps. Step 1 is and E gene screening assay. All negatives are to be considered as true negatives. All positive samples should be subjected to confirmation by Step $2 \mathrm{RdRp}$ gene confirmatory assay. All samples that test positive by this assay are considered as true positive.

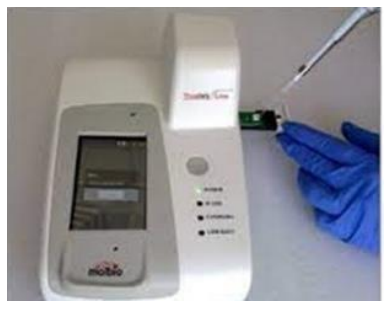

\section{E GENE and Rdrp} GENE 
3. LAMP: The presence of an active infection, by targeting specific gene sequences of SARS$\mathrm{CoV}-2$. This is typically qualitative. It relies on specially designed primers that help create the looped structures needed for amplification. It is very rapid and does not always require special equipment. It has a very low limit of detection of 125 viruses/ $\mathrm{mL}$.

Limitation is indesigning the primers needed can be complex, and debris can interfere with the reaction. It is also difficult to quantify the results.

4. Recombinase Polymerase Amplification: The presence of an active infection, by targeting specific gene sequences of SARS-CoV-2. This is typically qualitative. It relies on the recombinase enzyme. It is very rapid and does not always require special equipment. It has a very low limit of detection of 125 viruses $/ \mathrm{mL}$.

Limitation is in designing the necessary primers can be complex, and debris can interfere with the reaction. It is also difficult to quantify the results.

5. CRISPR-based diagnostics: The presence of an active infection, by targeting specific gene sequences of SARS-CoV-2. This is typically coupled with LAMP, but this is not always necessary. Results are typically visible to the eye, not requiring special equipment.

Limitation is it requires expert, specific design of components (ie, enzymes, primers, reporters).

\section{ANTIGEN AND ANTIBODY DETECTION TEST}

1. Rapid antigen detection Test: For qualitative detection of specific Nucleocapsid protein. COVID-19 Ag Rapid Test Device is an in vitro diagnostic rapid test in human nasal swab specimens from individuals who meet COVID-19 clinical and / or epidemiological criteria. The product may be used in any laboratory and non-laboratory environment that meets the requirements specified in the instructions for Use and local regulation. The test provides preliminary test results. Negative results don't preclude SARSCoV-2 infection and they cannot be used as the sole basis for treatment or other management decisions. Negative results must be combined with clinical observations, patient history, and epidemiological information. The test is not intended to be used as a donor screening test for SARS-CoV-2.

\begin{tabular}{|c|c|c|}
\hline Result & Control line & Test line \\
\hline Antigen positive & Present & Present \\
\hline Antigen negative & Present & Absent \\
\hline Invalid & Absent & Present \\
\hline
\end{tabular}

Limitation is it requires very careful design of synthetic antibodies, deep knowledge of viral proteins produced in various tissue environments, and may yield false negatives if the viral protein production is low.

2. Antibody detection Test: Serological assay is used side-by-side with molecular assay to support each other and used to identify the antibody protein i.e Immunoglobulin/ Ig which expressed as immune response to SARS CoV-2 as a specific viral pathogen. Serological assay particularly important for disease surveillance and to understand the epidemiology of SARS 
CoV-2 in order to estimation on morbidity and mortality rate which helps uncover the burden of disease.

The enzyme linked immunosorbent assay (ELISA), the virus isolation, the plaque reduction neutralization test (PRNT), and the lateral immunochromatography-based assay are currently developed both in-house or rapid format as serological evidence for SARS CoV-2 characterization.

ELISA based test is useful to determine the real infection rate in the population and is specific and sensitive allowing identification of SARS CoV-2 antibodies in post-acute phase; titre increasing after day 10th with human plasma/serum as inoculum.

Rapid antibody tests are useful for sero-surveillance purpose and survey in high-risk or vulnerable population like $\mathrm{HCW}$, frontline workers, immune compromised individuals, etc. Rapid antibody test is not recommended for clinical diagnosis of COVID-19 infection, enrolment of human subjects for any clinical trial, determining the immune status of an individual to declare him/her as recovered.

Viral Sequencing: Sequencing of the whole genome of SARS-CoV-2 with new generation sequencing systems is very important in terms of revealing the evolution of the virus, phylogenetic analysis, and vaccine and drug development studies. In the ongoing COVID-19 pandemic, using Wuhan-Hu-1/2019 as reference genome, spreading patterns are determined by analysing the known genetic variants and evolutionary relationships of SARS-CoV-2 and using the results of the analysis.

Viral Culture: The virus isolation is a gold standard for viral characterization aiming to get the pure isolate live viruses through propagation in the cell culture in vitro setting. For SARS CoV-2 the virus isolation is conducted in Vero E6 cell cultured in Minimum Essential Medium (MEM) with $2 \%$ of Fetal Bovine Albumin (FBS), 2mM L-glutamine, $20 \mathrm{mM}$ HEPES, and PenicillineStreptomycine (PenStrep) as supplementary. But not recommended as a routine diagnostic procedure.

How to Cite this article As: Madhulika Mistry (2021). Role of microbiology laboratory in diagnosis of sars cov-2 (Covid -19).

National Medicos Organisation Journal (एन एम ओ जर्नल) (ISSN-2348-3806), 15 (1), 19-26. Retrieved from https://nmojournal.org/index.php/nmojournal/index 